\title{
PEMBELAJARAN AKTIF (ACTIVE LEARNING): SUATU UPAYA PENGAKTIFAN SISWA DALAM BELAJAR MATEMATIKA
}

\author{
Oleh: Sefna Rismen*
}

\begin{abstract}
Active learning refers to learning process that encourages students to be more active in maximizing their mind, finding the key ideas of the teaching materials, solving problems and applying what have been learned into existing problems in real life. In other words, the learning activities will be more dominated by students. The aim of this approach is to increase students' involvement and activities in learning process. Such aim supports competency that the students are expected to achieve through learning activities: problem solving, critical thinking and communicating competencies.
\end{abstract}

Kata Kunci: pembelajaran aktif (active learning), aktivitas, penalaran, dan komunikasi.

\section{PENDAHULUAN}

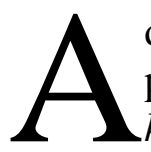

danya perubahan paradikma pendidikan dari teacher center ke student center, menuntut guru untuk dapat memvariasikan strategi ataupun metode mengajar. Salah satu caranya aalah dengan melibatkan siswa secara aktif. Sehingga pembelajaran tidak lagi didominasi oleh guru. Pada pembelajaran yang melibatkan siswa secara aktif, siswa harus dilibatkan baik secara fisik maupun mental. Siswa harus menkonstruksikan sendiri pengetahuannya baik secara sendiri-sendiri maupun secara bersama-sama dengan temannya. Sehingga, siswa mampu menggunakan pikirannya untuk menemukan ide pokok dari materi pelajaran, memecahkan masalah dan mengaplikasikan konsep keilmuannya dalam kehidupan sehari-hari.

Pada pembelajaran matematika, siswa diharapkan mampu mengkonstruksikan konsep-konsep atau prinsip-prinsip matematika dengan kemampuannya sendiri melalui proses internalisasi sehingga konsep dan prinsip itu terbangun kembali (Muliyardi, 2002:3). Sehingga, dalam proses pembelajaran matematika sangat diperlukan sekali peranan aktif siswa. Untuk itu, peran guru untuk memilih strategi atau metode mengajar yang melibatkan siswa secara aktif perlu diupayakan, baik secara mental, fisik, maupun sosial. Hal ini sejalan dengan tujuan pembelajaran matematika itu sendiri yakni (1) melatih cara berfikir dan bernalar dalam menarik kesimpulan; (2) mengembangkan aktivitas kreatif, mengembangkan kemampuan memecahkan masalah dan (3) mengembangkan kemampuan menyampaikan informasi atau mengkomunikasikan gagasan baik secara lisan maupun tulisan (Depdiknas, 2003)

Berdasarkan penjelasan di atas, dapat disimpulkan bahwa pembelajaran matematika berfungsi mengembangkan kemampuan berfikir, kemampuan mengkomunikasikan ide serta pemecahan masalah baik secara lisan maupun tulisan. Untuk mencapai tujuan tersebut seorang guru matematika dituntut untuk

* Penulis adalah Lektor dalam Mata Kuliah Statistika Elementer STKIP PGRI Sumatera Barat 
menggunakan strategi mengajar yang tepat dengan berbagai macam pendekatan dan metode serta teknik-teknik mengajar yang tepat agar siswa menjadi aktif dalam belajar.

Saat ini, banyak ditemukan strategi, model dan metode dalam pembelajaran matematika. Namun belum semua guru dapat menerapkannya atau menggunakan dalam praktek mengajar sehari-hari. Hal ini mungkin disebabkan oleh beberapa hal diantaranya kurangnya pengetahuan dan kemampuan guru, kurang kemauan dan kesadaran guru untuk memperbaiki proses pembelajaran, kondisi anak didik, atau kondisi sekolah yang tidak memungkinkan.

Artikel ini bertujuan menguraikan strategi pembelajaran yang dapat mengaktifkan siswa dalam proses pembelajaran matematika, untuk bisa digunakan dalam proses pembelajaran oleh guru.

\section{PEMBELAJARAN AKTIF (ACTIVE LEARNING)}

Active Learning pertama kali dikembangkan oleh Melvin Silberman, seorang guru besar kajian psikologi pendidikan di Temle Universitas yang berspesialisi dalam psikologi pengajaran. Tujuan dari metode ini adalah untuk meningkatkan aktivitas siswa dalam belajar. Active Learning ini dikembangkan dari pernyataan konfusius 2400 tahun yang lalu dalam Silberman (2006:23), yaitu yang saya dengar saya lupa, yang saya lihat saya ingat, yang saya kerjakan saya pahami.

Selanjutnya, pembelajaran aktif didefenisikan oleh Hisyam (2004:16) sebagai: suatu pembelajaran yang mengajak siswa untuk belajar secara aktif dimana siswa mendominasi aktivitas pembelajaran. Dengan secara aktif menggunakan otak, untuk menemukan ide pokok dari materi pelajaran, memecahkan persoalan dan mengaplikasikan apa yang baru dipelajari ke dalam suatu persoalan yang ada dalam kehidupan nyata.

Silberman (2006;23) memperluas pernyatan menjadi Paham Belajar Aktif (Active Learning Credo) yaitu: yang saya dengar, saya lupa. Yang saya dengar dan lihat, saya sedikit ingat. Yang saya dengar, lihat, dan pertanyakan atau diskusikan dengan orang lain, saya mulai pahami. Dari yang saya dengar, lihat, bahas, dan terapkan, saya dapatkan pengetahuan dan keterampilan. Yang saya ajarkan kepada orang lain, saya kuasai.

Menurut penulis, dalam memahami sesuatu tidaklah cukup dengan mendengar dan melihat saja. Jika siswa bisa "melakukan sesuatu" dengan informasi yang diperoleh, siswa akan memperoleh umpan balik mengenai seberapa bagus pemahamannya, maka siswa akan mendapatkan pengetahuan dan keterampilan. Kenyataannya, siswa sulit untuk berkonsentrasi dan siswa cenderung bosan bila hanya melakukan aktivitas mendengar dalam waktu lama. Untuk itu, dalam pembelajaran aktif semua panca indra siswa dilibatkan untuk mendapatkan pembelajaran yang lebih bermakna. Hal ini sesuai dengan yang dikatakan Wycoff (2002) dalam Armiati (2003:5) bahwa informasi yang melibatkan lebih dari satu indera akan lebih mudah diingat dibandingkan dengan informasi yang hanya dialami oleh satu indera.

Dari uraian di atas dapat disimpulkan bahwa strategi pembelajaran aktif adalah strategi yang menuntut keaktifan siswa menggunakan pikirannya baik menemukan ide pokok dari materi pelajaran, memecahkan masalah dan mengaplikasikannya ke dalam suatu persoalan dalam kehidupan nyata.

Belajar aktif juga menuntut keaktifan siswa secara aktif menuju belajar mandiri dan banyak mengerjakan tugas sebagaimana yang dikemukakan oleh Dede (2004:165): belajar aktif adalah be- 
lajar yang memperbanyak aktifitas siswa dalam menganalisis berbagai informasi dan berbagai sumber untuk mereka bahas dalam proses pembelajaran dalam kelas, sehingga memperoleh berbagai pengalaman yang tidak saja menambah kompetensi pengetahuan mereka, tetapi juga kemampuan analisis, sintesis, dan menilai informasi yang relevan untuk dijadikan nilai baru dalam hidupnya.

Pada proses pembelajaran, siswa dianggap belajar aktif apabila telah melakukan aktivitas dan melakukan tindakan yang aktif seperti membuat pertanyaan, berdiskusi dan lain-lain. Keaktifan siswa tidak hanya secara fisik tetapi juga mental. Menurut Subroto (1997:71) keaktifan siswa dapat dilihat dari (a) berbuat sesuatu untuk memahami materi pelajaran dengan penuh keyakinan; (b) mempelajari, memahami, dan menemukan sendiri bagaimana proses pengetahuan; (c) merasakan sendiri bagaimana tugas-tugas yang diberikan guru kepadanya; (d) belajar dalam kelompok; (e) mencoba kembali konsep-konsep tertentu; dan (e) mengkomunikasikan hasil pemikiran, penemuan, dan penghayatan nilai-nilai secara lisan atau penampilan.

Menurut penulis, dalam kegiatan belajar aktif, siswa dituntut untuk mencari jawaban atas sebuah pertanyaan, membutuhkan informasi untuk memecahkan masalah atau mencari cara untuk mengerjakan tugas. Pendapat ini diperkuat oleh John Hoolt (1967) dalam Silberman (2006:4) yang mengatakan bahwa proses belajar akan meningkat jika siswa diminta untuk melakukan (a) mengemukakan kembali informasi dengan kata-kata mereka sendiri; (b) memberikan contohnya; (c) mengenalinya dalam bermacam bentuk dan situasi; (d) melihat kaitan antara informasi itu dengan fakta atau gagasan lain; (e) menggunakannya dengan beragam cara; (f) memprediksikan sejumlah konsekuensi- nya dan (g) menyebutkan lawan atau kebalikannya.

Pembelajaran bermakna tidak akan terwujud jika tidak ditemukan kegiatan diskusi, mengajukan pertanyaan, bekerja, dan bahkan mungkin mengajarkan rekan sesama siswa. Menurut Armiati (2003:5) untuk memahami materi matematika mahasiswa perlu membaca, menulis, menghubungkan hasil bacaanya dengan sesuatu. Misalnya dengan soal yang sedang ia bahas, maka pemahamannya terhadap materi matematika yang sedang dipelajari akan lebih baik.

Sehubungan dengan pendapat di atas pembelajaran aktif sangat cocok diterapkan dalam pelajaran matematika, karena dalam belajar matematika siswa tidak hanya dituntut untuk terlibat fisik tetapi secara mental mutlak diperlukan karena konsep matematika tidak dapat dipahami dengan membaca saja, tetapi harus dituliskan atau digunakan dalam penyelesaian berbagai masalah matematika.

\section{BEBERAPA JENIS-JENIS STRA- TEGI PEMBELAJARAN AKTIF}

Ada 101 jenis strategi pembelajaran yan dikemukan oleh Silberman, namun dalam tulisan pertama ini dijelaskan hanya tiga strategi pembelajaran aktif, penjelasannya sebagai berikut:

\section{Strategi Pembelajaran Aktif Syner- getic Teaching}

Menurut Silberman (2006:128) strategi pembelajaran Synergetic Teaching memungkinkan para siswa yang memiliki pengalaman berbeda dalam mempelajari materi yang sama untuk saling membandingkan catatan. Selanjutnya Hisyam (2004:35) menjelaskan Strategi Synergetic Teaching adalah strategi yang menggabungkan dua cara belajar yang berbeda. Strategi ini memberikan kesempatan kepada siswa untuk saling 
berbagi hasil belajar dari materi yang sama dengan cara yang berbeda dengan membandingkan catatan mereka. Sehingga bisa disimpulkan, bahwa strategi Synergetic Teaching adalah penggabungan dari dua cara belajar yang berbeda dengan materi yang sama dengan cara membandingkan catatan. Strategi ini membuat siswa lebih mudah untuk memahami materi dengan berbagi pengalaman belajar, selain dapat membuat temannya mengerti dengan yang dijelaskan maka siswa yang menjelaskan juga akan bertambah paham terhadap materi yang dipelajari.

Adapun prosedur pembelajaran dengan strategi Synergetic Teaching menurut Siberman (2006:129) adalah:

1. Bagilah kelas menjadi dua kelompok.

2. Kirimkan satu kelompok ke ruang lain untuk membaca topik yang Anda ajarkan. Pastikan bahwa materi bacaannya tertata dengan baik dan mudah dibaca.

3. Dalam pada itu, berikanlah pelajaran berbasis ceramah atau lisan tentang materi yang sama dengan yang sedang dibaca oleh kelompok yang ada di ruang sebelah

4. Selanjutnya, baliklah pengalaman belajarnya. Sediakan materi bacaan tentang topik Anda untuk kelompok yang telah mendengarkan penyajian mata pelajaran dan sediakan materi pelajaran untuk kelompok pembaca

5. Pasangkan anggota dari tiap kelompok dan perintahkan mereka mengikhtisarkan apa yang telah mereka pelajari.

\section{Model Pembelajaran Group To Group Exchange (GGE)}

Dalam pembelajaran tipe GGE setiap kelompok diberi tugas yang berbeda, dan masing-masing kelompok mengajarkan apa yang telah dipelajarinya di depan kelas. Sehingga setiap kelompok siswa berkesempatan untuk bertindak sebagai kelompok ahli untuk kelompok siswa lainnya setelah mengerjakan tugas yang diberikan pada kelompok tersebut. Model ini merupakan strategi yang mudah untuk mendapatkan partisipasi dan akuntabilitas individual dari seluruh kelas (Silberman, 2006: 112).

Prosedur pembelajaran tipe GGE menurut Silberman (2006:158) adalah:

1. Memilih suatu topik yang mengandung beragam gagasan, peristiwa, posisi, konsep atau pendekatan untuk ditugaskan pada siswa. Topik tersebut haruslah dapat membuat siswa bertukar pandangan atau informasi (Sebagai bahan untuk diskusi).

2. Membagi kelas itu ke dalam kelompok sesuai dengan banyak tugas. Kemudian memberi masing-masing kelompok waktu yang cukup untuk mempersiapkan penyajian topik yang ditugaskan pada kelompok tersebut.

3. Ketika tahap persiapan telah diselesaikan. Mintalah pada kelompok untuk memilih siapa juru bicaranya. Mintalah masing-masing juru bicara untuk mempresentasikan tugas tersebut secara jelas dan ringkas. Selanjutnya, mintalah kepada kelompok lainnya untuk mengajukan pertanyaan atau tanggapan mereka sendiri terhadap presentasi kelompok penyaji. Apabila ada pertanyaan yang meragukan kelompok penyaji untuk menjawab maka anggota kelompok lain diizinkan untuk menjawab.

4. Melanjutkan presentasi berikutnya dari kelompok yang berbeda. Sedemikian sehingga masing-masing kelompok dapat membandingkan informasi dan pandangan yang telah didapatnya.

\section{Strategi Aktif Tipe Everyone Is a Teacher Here (ETH)}

Strategi pembelajaran ETH adalah salah satu strategi belajar dengan siswa 
yang berperan sebagai seorang guru. Materi yang disampaikan oleh teman sendiri lebih mudah untuk dipahami karena latar belakang pengalaman dan pengetahuan. Selain membuat temannya mengerti dengan yang dijelaskannya maka siswa yang menjelaskan juga akan bertambah pemahamannya.

Menurut Silberman (2006:183) prosedur pembelajaran dengan tipe ETH ini adalah:

1. Edarkan kartu indeks pada tiap siswa. Mintalah tiap siswa untuk menuliskan pertanyaan tentang materi pelajaran yang sedang dipelajari.

2. Kumpulkan kartu, kocok, dan berikan kembali kartu tersebut pada tiap siswa. Mintalah siswa untuk membaca pertanyaan yang ada ditanganya dan memikirkan jawabannya.

3. Mintalah seorang sukarelawan untuk membacakan pertanyaan dan memberikan tanggapan atau jawabannya serta menjelaskan pada temannya.

4. Mintalah siswa lain untuk menambahkan atau menanggapi pendapat sukarelawan tadi.

\section{DAFTAR RUJUKAN}

Armiati dkk. (2003). Suatu Model Pembelajaran Aktif dalam Mempelajari Mata Kuliah Diskrit Melalui Pemberian Tugas Terstruktur Dengan Koreksi Silang. Laporan Penelitian. Padang : UNP.

Hisyam Zaini dkk. 2004. Strategi Pembelajaran Aktif. Yogyakarta: CTSD (Center For Teaching Staff Development).

Hoolt, Jhon. (1993). Psikologi Pendidikan. Jakarta : P2LPTK.

Muliyardi.2002. Strategi Pembelajaran Matematika. Padang: Jurusan FMIPA UNP.

\section{PENUTUP}

Guru sebagai pengajar juga dituntut untuk menggunakan strategi ataupun metode mengajar yang sesuai dengan materi pengajaran, sehingga siswa menjadi lebih mudah dalam memahami materi yang diajarkan. Seperti yang dikemukakan oleh Hisyam (2004:16) bahwa guru harus dapat menyampaikan materi pelajaran dengan strategi bervariasi dan melibatkan siswa secara aktif. Tujuan agar siswa mempunyai jiwa kemandirian dalam belajar dan diusahakan untuk menumbuhkan daya kreatif siswa.

Agar pembelajaran aktif dapat terlaksana dengan baik, maka guru perlu: (1) memiliki komitmen yang tinggi dalam melaksanakan tugas; (2) selalu melakukan inovasi-inovasi dalam pengajaran; (3) selalu menciptakan iklim belajar yang kondusif dan (4) memiliki motivasi yang tinggi.

Silberman, Melvin. 2006. Active Learning (101 Cara Belajar Siswa Aktif). Bandung: Nusamedia.

Subroto, Surya. 1997. Proses belajar mengajar di sekolah. Jakarta, Rineka Cipta

Depdiknas, 2003. Standar Kompetensi Mata Pelajaran Matematika Sekolah Menengah Atas dan MA, Jakarta. Dirjen Pendidikan Dasar Menengah Depdiknas RI 


\section{Indeks}

aktif, 53, 146, 147, 148, 149, 150

aktivitas, 53, 146, 147

komunikasi, 53

matematika, 53, 146, 147 pembelajaran, 53, 146, 147, 148, 149, 150

penalaran, 53 